\title{
Tax incentives/disincentives to sustainable forest management: A review of the Curtis Study recommendations
}

\author{
Bruce Lunergan, CA, CMA
}

\section{Introduction and Background}

In 1992 the Canadian Forestry Association published a study entitled "Tax Reform for Private Woodlot Owners in Canada." The study was authored by David Curtis and has become known as the Curtis Study; it made a number of recommendations for changes in the Canadian tax system as it relates to woodlot owners.

Over the past several years a concern has arisen, to varying degrees across Canada, that there is serious over cutting of private woodlots. This over cutting is the result of liquidation harvesting approaches being applied to many more woodlots than in previous years. This concern has increased the interest in sustainable forest management approaches.

Clearcutting is an acceptable harvesting method under certain forest conditions. The frequency of such conditions varies from one forest region to another across the country. However, indiscriminate clearcutting, sometimes referred to as liquidation harvesting, is undesirable from a forestry point of view. Partial cutting methods, such as selection harvesting, are very desirable as a means of achieving sustainable production of forest products and other values.

The increase in liquidation harvesting has been driven by the wood market and by some other factors. There is a concern that the Canadian income tax system inadvertently favours liquidation harvesting over more sustainable harvest methods such as selection harvesting approaches.

The purpose of this paper is to review the Curtis Study recommendations; to see if they are still valid today, and in particular, to assess their impact on the choice of harvesting methods used. First, we must understand what tax incentives or disincentives exist in respect of sustainable forest management. To do this, we need to understand the tax situations and motivations of the various groups of actors: clearcut operators, sustainable operators, and non-operator owners of woodlots. In particular, we want to look at those issues which will effect the choices made by non-operator owners. The operators have made a set of decisions on how they wish to operate and an investment in the skills and equipment necessary to carry out their plan of operation. Non-operator owners are less constrained by prior decisions.

\section{The "Clearcut" Operator}

The clearcut operator includes income from the sale of wood in income. S/he deducts the costs of harvesting and the cost of wood acquired.

If wood is acquired by purchasing land then the cost of wood is the cost of the property minus the residual value of the cutover land. This cost, known as depletion, is deducted in the proportion that the volume of wood cut is of the original volume of wood acquired. If one assumes that the clearcut operator will cut all of the wood on a property then s/he will deduct all of the cost.
If the clearcut operator is working as a contractor on land owned by another person then the cost of the wood harvested is the stumpage cost.

The clearcut operator typically makes his or her living doing logging work and has a substantial investment in equipment designed for clearcutting operations. S/he need to achieve high volumes in order to utilize both machine and labour capacity. This encourages him/her to seek out opportunities to apply their harvest techniques.

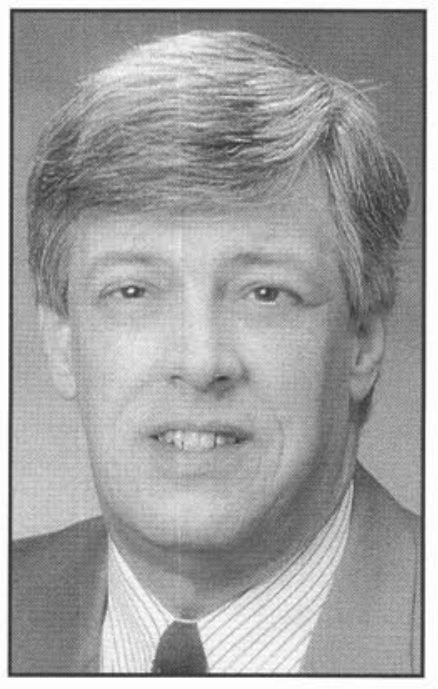

\section{The "Sustainable" Operator}

The sustainable operator may have income from contract work on property owned by others. This is taxed in the same way that contracting income of a clear-cut operator is taxed. We are more concerned with the owner-operator situation.

The sustainable operator is essentially taxed as the clearcut operator is. The income from the sale of wood is included in income and harvesting and wood costs are deducted.

Because the depletion deduction is based on the volume of wood cut, the sustainable operator will deduct the cost of wood acquired over a much longer time period than will the clearcut operator. This is because the sustainable operator takes a much longer time to cut the wood. Nevertheless, s/he does get the deduction and because it is based on the volume of wood cut, there is a reasonable matching of the deduction with the revenue.

The sustainable operator may have some silviculture costs in addition to the above. These costs are deductible from income, although there is a question as to whether these costs must be inventoried, i.e., added to the cost of the standing timber and only deducted when the wood is cut. Naturally, if a clearcut operator incurred similar costs s/he would also get a deduction.

A sustainable operator may have an irregular pattern of revenue which can be a concern. If revenues are only occurring every third year, for example, and some costs are incurred each year then the revenue can be taxed in a higher tax bracket than the expenses are deducted in. This might be addressed by some form of income averaging.

Another area of concern with this group is the operator with an immature property which will not generate revenue for many years. The deductibility of expenses becomes uncertain in this situation. A higher level of certainty is needed.

Due to the relatively small size of most woodlots, owners typically do not make their primary living from their forestry 
activities. The sustainable approach fits with this because it does not require the intensity of effort that clearcut operations do. The sustainable operator probably has some aesthetic or environmental reasons for the choice of operating style as well.

On an economic basis, the sustainable operation will result in more production from the forest. The operator must believe that the long term return from sustainable management will be greater.

\section{The Non-operator Owners}

The only revenue that a non-operator owner will generate from a woodlot is infrequent or "once in a lifetime" sales of stumpage. These are treated as capital receipts on a cost recovery basis. In other words, they are applied to reduce the cost of the property first, then any receipts in excess of the cost of the property become a capital gain. A capital gain is more desirable than business income because only $75 \%$ of a capital gain is included in income.

The advantage of capital gains treatment has been compounded by the availability of the capital gains deduction which could have allowed a woodlot owner to receive stumpage payments free of tax. While the general capital gains deduction was eliminated on February 22, 1994 many woodlot owners would have taken advantage of the election available to use the deduction. Their woodlots now have fairly high cost bases available to shelter stumpage payments from tax.

A contrary effect results from the fact that any income or capital gain may cause the clawback of Old Age benefits or a reduction in the guaranteed income supplement. Despite the fact that they would have more after-tax cash if they had their woodlot harvested, this will cause some older woodlot owners to do nothing with their property. Whether a large, one-time harvest or regular, smaller harvests are more desirable is dependent on the woodlot owner's level of income.

While some non-operator owners are conscious of the value of their woodlots and may even apply some silvicultural techniques to enhance their return, many are not. The woodlot was inherited, acquired "as an investment" or is primarily recreational and the owner has no specific plan to management the forest.

\section{Assessing the Curtis Study Recommendations}

Given the above background, we can now ask whether the recommendations in the Curtis Study still make sense. We shall consider them individually.

\section{Recommendation 1}

Recommendation 1 is to include a definition of a woodlot manager in the Income Tax Act. More appropriately, this should probably be a definition of woodlot management. This recommendation was made, in part, to help deal with the issue of whether a business was being carried on. This issue can be dealt with under recommendation 2. A clear definition in the Income Tax Act would help facilitate other legislative measures. The recommendation is very important if other measures are taken either now or in the future.

\section{Recommendation 2}

Recommendation 2 is to allow deductions for expenses incurred in respect to a woodlot against income from all sources. This recommendation is effectively in place: bona fide business loss- es are deductible against income from all sources. The difficulty lies in the practical application of this, given the concept that there must be a reasonable expectation of profit before any activity can be considered a business.

The sustainable operator can have costs for silviculture treatments, for planning or for the installation of roads, which occur well in advance of any revenue. And they can have ongoing costs for interest and property taxes. Despite the differences in timing of these costs and the revenues generated by them they are bona fide costs of the business and should be allowable as deductions from income.

This is an area which greatly concerns woodlot owners. There is a lack of clarity in how Revenue Canada will apply the reasonable expectation of profit concept to woodlots. This creates uncertainty, which leads to inactivity, so sometimes no management activities are undertaken.

Revenue Canada has undertaken a project to revise Interpretation Bulletin IT-373R. In conjunction with this, the Canadian Federation of Woodlot Owners has supplied Revenue Canada with some reasonable tests that would help establish whether a woodlot operation was being carried on with a reasonable expectation of profit. These suggested tests are:

\section{- Has serious planning been undertaken?}

- Has the owner made a serious effort to implement the plans?

- Does the owner invest in the expertise necessary to carry out good quality planning and implementation?

It is recommended that this project be completed as soon as possible, as part of a comprehensive approach to defining the unique characteristics of woodlot managers and woodlot businesses.

\section{Recommendation 3}

Recommendation 3 is to allow woodlot managers to use cash basis accounting. This recommendation was largely intended to make income computation simpler for the woodlot operator. In particular, it was designed to remove any necessity to inventory costs related to standing timber.

Other than the inventory issue there is little difference between cash and accrual based income in the context of a woodlot, the industry standard is that payment is made quite promptly so there is no reason not to use the accrual method. Costs which might be inventoried could simply be expensed, without undue revenue loss. We recommend that the uncertainty surrounding this area could be dealt with by setting out a position the silviculture expenses do not have to be inventoried in the revised IT Bulletin discussed above.

\section{Recommendation 4}

Recommendation 4 is to allow a deduction for the cost of purchased wood in the year of acquisition; essentially, a $100 \%$ depletion.

- For the clearcut operator there would be no effect, they are basically getting that deduction now.

- For the non-operator there would be no effect: they do not get, nor need, a depletion deduction if their receipts are on account of capital. 
- For most sustainable operators there may not be much benefit. They would have a large deduction which they may not have the income to absorb. It would be deducted at the low rate, waste their personal credits and then be carried over to other years. When they did have income they would not have the depletion deduction to offset it which would worsen the bracket swing problem discussed earlier.

- For larger sustainable operators with sufficient income to use the deduction there would be some incentive to acquire and manage more land.

This recommendation would allow a deduction for the cost of standing timber purchased even if the wood was not cut but say, for example, destroyed by fire. This would somewhat reduce the risk associated with the business.

A significant drawback with this proposal is that it is an incentive to acquire a woodlot, not an incentive to manage one. At its worst, it could encourage acquisition of woodlots as tax shelters. The requirement for a management plan would temper this somewhat but the plan could easily be abandoned after the deduction is obtained. Access to the deduction would be limited by the requirement to be carrying on business discussed under recommendation 2 above.

While this recommendation would provide some incentive to practice sustainable management if would only effect a limited number of taxpayers. Offseting this is the significant potential for abuse that this recommendation would create. On balance the recommendation should be dropped.

\section{Recommendation 5}

Recommendation 5 is to allow woodlot owners to elect to treat their woodlot as being either income or capital properties.

- For clearcut operators this produces an absurd result. They are clearly carrying on a business and should be taxed at full business rates. If they did treat the property as on account of capital many of their costs would not be deductible, most notably Capital Cost Allowance.

- For non-operators there would be no change, they get capital property treatment now.

- For sustainable operators there is still the argument that they are carrying on a business and receipts should not be on capital account. Because of the smaller volume and irregular revenue streams there might be some argument to overlook this. They would still have some lost expenses as the clearcut operator would although this would not have the same impact because sustainable operations are not so equipment intensive. The net effect may be some incentive to acquire and manage more land.

To provide different treatment for clearcut and sustainable operators would present significant enforcement problems.

We recommend leaving things generally as they are but provide more certainty as to Revenue Canada's position as is suggested below. Again, this could be included in the revised IT Bulletin.

Since the Curtis Study was published, Revenue Canada's position on capital treatment for sales of standing timber (stumpage) has changed somewhat from "woodlots incidental to farms" to "all woodlots" and from "once in a lifetime" to "infrequent."
To encourage sustainable management the policy should be that infrequent, say every 10 to 20 years, stumpage receipts would generally be on account of capital. The belief that stumpage must be once in a lifetime encourages a liquidation harvest. Capital treatment would, of course, still have to be determined on the facts of a given situation since there could be circumstances where income treatment should apply even if harvesting is infrequent.

Woodlot owners who will treat stumpage receipts as capital would not be able to deduct expenses incurred with respect to their woodlot, but these costs should be added to the cost of the property. We recommend that this information be included in the revised Interpretation Bulletin.

\section{Recommendation 6}

Recommendation 6 is really two separate recommendations:

The first is that woodlots be eligible for the enhanced, $\$ 500,000$ capital gains deduction. This is based on the premise that they are similar in nature to farms. Some woodlots are considered farms, e.g. a Christmas tree farm, and would be eligible for the deduction. This recommendation would encourage investment in woodlot management to build value and thus is positive with respect to sustainable management. On the other hand, it could encourage passive behaviour so that proceeds from harvesting would be treated as tax-free capital receipts. This recommendation should be considered from a consistency standpoint, that is, that taxpayers in similar situations be treated similarly. This recommendation would require legislative change.

The second part of the recommendation is to allow tax deferred intergenerational transfers similar to those provided for farm properties. This recommendation would have a positive impact on the decision to choose sustainable forest management. management. The time horizons involved in a sustainable approach are long-term. If the woodlot owner perceives that the benefits will continue to accrue to their family they will be more willing to choose a sustainable approach. Again, this recommendation would require legislative change.

\section{Recommendation 7}

Recommendation 7 is to establish tax credits to encourage investment in woodlots, woodlot management and equipment.

There is already some investment tax credit available in the Atlantic region with respect to equipment. Generally, however, investment tax credit programs are being phased out so other incentives are probably more desirable. If tax credits are used they should be refundable because many woodlot owners may have incomes that are too low to use non-refundable credits.

There are currently some assistance programs available for woodlot management, e.g., to offset thinning costs. These could be expanded particularly to include the development of management plans. Expanded grant programs should be tied to the use of sustainable management techniques.

\section{Recommendation 8}

Recommendation 8 is to provide some mechanism to shelter income from a woodlot to allow it to be used for woodlot management costs in the future. 
Reforestation costs should be treated as a cost of the crop harvested rather than of a future crop. Where a taxpayer has capital receipts from the harvest of a property and undertakes reforestation within a reasonable period of time they should be allowed to amend the tax return for the year the harvest occurred and treat the reforestation costs as a cost of disposition.

This could be accomplished by some form of registered fund to which the woodlot owner would make a deductible contribution based on woodlot source income. Withdrawals would be included in income but would have to be used for reforestation purposes. Some form of penalty provision would be needed to prevent the plan from simply becoming an income averaging mechanism.

An alternative approach would be rules similar to the replacement property rules which would allow amendment of prior year returns to carry back reforestation costs against the proceeds from the harvest.

\section{Summarizing the Recommendations}

Legislative changes (in order of priority) should be made:

- To define woodlot management in the Income Tax Act;

- To provide for tax deferred intergenerational transfers of woodlots;

- To make all woodlots eligible for the enhanced capital gains deduction;

Priority should also be given to completing the revision of IT-373R. The revisions should provide for the following:
- Guidance on the application of the concept of reasonable expectation of profit that is consistent with the nature of the woodlot sector;

- A statement that there is no requirement to inventory costs related to standing timber;

- A statement that infrequent stumpage receipts will be treated as on account of capital in most cases;

- A statement that costs related to a woodlot where there is no business being carried on are added to the property's adjusted cost base.

A longer term recommendation is to consider some mechanism which would allow deduction of reforestation costs against the crop harvested.

\section{Conclusion}

This paper has considered the Curtis Study, which detailed concerns about the relationship between sustainable woodlot management and the Income Tax Act. Beginning with an overview of various situations facing those who grow, maintain and dispose of woodlots, the paper also considered discussions between interested parties, before, during, and after the October 1997 meeting of the Roundtable on the Environment and the Economy .

It has presented a background to the subject, overviewed the Curtis Study recommendations, and proposed changes in the tax system in keeping with those recommendations. It is hoped that those involved in all aspects of sustainable woodlot management will use this paper as a starting point, in the search for solutions that are environmentally and economically efficient, while fair to all from a taxation standpoint. 